\title{
Possibility of Applying Arabian Management Theory
}

\author{
Mohammed Mufaddy Al-Kasasbeh ${ }^{1}$ \\ ${ }^{1}$ Business Management, Faculty of Business, Amman Arab University, Jordan \\ Correspondence: Mohammed Mufaddy Al-Kasasbeh, Business Management, Faculty of Business, Amman Arab \\ University, Jordan. E-mail: mkasasbeh2002@yahoo.com
}

Received: June 6, 2016

Accepted: July 28, 2016

Online Published: September 20, 2016

doi:10.5539/ijbm.v11n10p270

URL: http://dx.doi.org/10.5539/ijbm.v11n10p270

\begin{abstract}
The research aims at examining the possibility of applying Arabian management theory by measuring the impact of Arabian management theory pillars (service concept, counseling concept, and justice concept) on employees' performance. A survey questionnaire was distributed to 385 employees at private, public, civil society, and regional organizations in 22 Arabian countries by e-mail to collect the relevant data about research constructs, and test the study hypotheses, where 202 valid questionnaires were retrieved from 14 Arabian countries (Algeria, Bahrain, Egypt, Iraq, Jordan, Kuwait, Morocco, Palestine, Qatar, Saudi Arabia, Sudan, Syria, UAE, and Yemen); which represents 52.47\% from distributed questionnaires and 63.64\% from Arabian countries.
\end{abstract}

The study has detected the following findings:

- The perceptions of respondents about all items of Arabian management theory pillars (service concept, counseling concept, and justice concept) are high.

- There is a statistical impact of Arabian management theory pillars (service concept, counseling concept, and justice concept) on employees' performance.

- There are no statistically differences at significant P-value $<0.05$ in perceptions of respondents towards Arabian management theory pillars (service concept, counseling concept, and justice concept) attributable to nature of organization.

- There are no statistically differences at significant P-value $<0.05$ in perceptions of respondents towards Arabian management theory pillars (service concept, counseling concept, and justice concept) attributable to their countries.

Based on the findings of the study, private, public, civil society, and Arab regional organizations in Arab world are advised to apply Arabian management theory pillars in order to enhance its role in employees' performance through recruiting and hiring leaders who believe in Islamic values and Arab culture. Future studies could be conducted in terms of Arabian management theory on job satisfaction and other related constructs.

Keywords: Arabian management theory, service concept, counseling concept, justice concept, employees' performance, Arab organizations, Arab nations

\section{Introduction}

Management as an activity and practice is found in all communities and nations, where its existence in homes, places of worship, governance, and all economic activities. Management has been, and is still the greater hand for every leader. All great leaders throughout history were managers; through managing the affairs of their countries, and running the efforts of their people (AL-Kasasbeh, AL-Faouri, \& Al-Hyasat, 2012).

Management plays a vital role at the development of organizations in the all countries. Accordingly, a number of management theories emerged (Abu Nabaa, 2014). Despite the existence of management as a practice since ancient civilizations, where management has been practiced for thousands of years (Robbins, DeCenzo, \& Coulter, 2013), but management as science did not appear only at the end of the nineteenth century and the beginning of the twentieth century when classical, behavioral, and quantitative schools grew up. Then, modern management theories emerged (AL- Ameri \& AL-Ghalibi, 2013). Management theories were developed in the way of studying the productive activities of industrial firms, but there are several organizations and human communities, where an extensive use of management theory outcomes can be effective (Butkus, 2010). The search will continue to formulate more theories in order to improve performance in organizations. 
Organizations faced challenges in the 21st century. These challenges forced the organizations to review its strategic approaches, adapt to its environments through new methods such as building smart and virtual organizations (AL-Kasasbeh, AL-Kasasbeh, \& AL-Faouri, 2016).

In cross-cultural settings, earlier studies of management used the approach of transferring management theories, methods, know-how, and practices from more developed to developing countries. Researchers from the various disciplines have participated in the efforts of organization theory. Cross-cultural management scholars have been moving towards exploring the motivations, aspirations, and attitudes of human beings around the world; mainly those located in the developing countries (Saikat, 2005).

At this time of so-called Arab Awakening, organizations in the Arab world nowadays face serious challenges and concerns in terms of quality of life, total quality management, and organizational sustainability. Hence, managers might need to re-engineer their ways of thinking to become more attuned with Arab values and culture (Hammoudeh, 2012).

Abu Nabaa (2005) has developed a new management theory in his book titled "Toward Developing an Arabian Theory in Management". This book contributes in enhancing management thought based on Arabian and Islamic heritage instead of consuming the Western theories which may not be applicable in Arabian environment.

Despite some practices and ideas from the past are still applicable and relevant to management today (Daft, 2013), but successful resolution of organizational problems is depend on managers' identification of key variations in culture, environment, and situation at hand. Therefore, the aim of current study is to examine the possibility of applying Abu Nabaa's management theory in Arabian context.

\section{Literature Review \& Study Hypotheses}

Marti and Scherer (2016) indicated that management theories are not only describing organizational reality but also shaping it, therefore, management researchers should take social welfare considerations into account in their theories and empirical studies. Jones, Donaldson, Edward, Harrison, Leana, Mahoney, and Pearce (2016) recommended that management scholars would be inspired to directly address social welfare concerns in their theorizing and empirical researches. And if theory building do shape organizational reality, the better world envisioned by the management scholars may begin to take shape in workplace.

Obeidat, Shannak, Masa'deh, and Al-Jarrah (2012) have examined the heritage and religious features of Arabian culture and its implications for managers at organizations in the Arab nations. The study has indicated that the characteristics of Arabian culture differ from those of Western nations, accordingly different management theories and practices need to be developed in Arabian organizations rather than adopting Western theories and practices. Obeidat et al. study's (2012) has determined the managerial problems of Arabian organizations and suggested that managers need to be aware of their own cultural issues, and the vitality of paying their attention to avoid negative consequences on the organizational performance. There is a vital need in the Arab world to build cooperation mechanism for the exchange of experience and knowledge among professionals dealing with culture and heritage management (Alghazawi, Waheeb, \& Kraisha, 2015).

Smith, Choui, and Harb (2007) concluded study to understand cross-national variations in leadership by examining how leaders handle specific work events within their span of control. Smith et al. study's (2007) samples were middle and senior managers in four Arab countries. Saudi managers were found to be an expected traditional and personality style of fairly strong reliance on both formal and unwritten rules. Managers from Qatar, Lebanon and Oman each differed from this style in ways consistent with modern theories. Correlations with assessments of how routine work events had been handled in each country revealed the presence of distinct leader styles. The conclusion of the study indicated that there is a fairly uniform style of leadership across Arab countries.

Saikat's study (2005) provides an analysis of cross-cultural management style and structure to support the young American managers in multinational companies who are placed in charge of foreign offices. By understanding the reasoning behind each other's behavior, there would be less room for inaccurate generalizations. However, all managers and employees have to receive some type of training in cross-cultural organization styles.

Since the discovery of oil, Arab world has become a center of international attention. Due to the peculiarity of the change process in the Arab nations. Arab work orientations, practices, and management styles, are neither known nor understood outside the Arab region. Therefore, organizational development accomplishments are still limited (Ali, 1996).

Culture and environment have been considered as significant elements in management studies. Culture particularly is perceived by many scholars as a crucial element in differentiating Eastern management practices 
from those in the West. Culture, also, plays a vital role in Arab society. Distinctive social, historical, and religious customs require that more attention to be paid to cultural traits in the exercise of authority, interaction and control (Alyousif, Naoum, Atkinson, \& Robinson, 2010).

Findings of Badawy's study (1980) suggest that philosophies and managerial styles of Arab managers from Bahrain, Kuwait, Saudi Arabia, UAE, and Oman are traditional affected by their history and culture.

Abuznaid (2006) developed a model for the effect of Islam on managers' behavior. The effect is employed from the pillars of Islam: faith, prayer, alms, fasting, and pilgrimage. He found an evident that the five pillars have a significant impact on managers' behavior. Moreover, he concluded that there is a direct effect of Allah supreme names on managers' style and behavior. Allah names have a significant relationship with management functions such as planning, organizing, and directing. Likewise, the combination of nationality and religion is a form of identification of the majority for Arab cultures. Religion has a main impact on social interactions, human behavior and social relations.

Ali (1990) detected that developing countries would face social and managerial problems. One of these problems is transferring of Western management models, practices, and techniques to be used in developing countries. Where Arab countries provide a unique setting for social- science study and analysis, due to the rate of changes, direction, and complexity.

Abu Nabaa (2005) has built his Arabian theory in management on the following three pillars:

The first pillar is service: manager has to respect his employees as he respects his guests to win their cooperation and improve their performance. The second pillar is counseling with his people and giving them opportunities to participate in decision making process that motivate employees and improve their performance. The third pillar is justice. Manager has to consider fear of Allah when taking any decision, and has to be fair with all employees, therefore, employees' performance will be improved. Figure 1 shows Arabian theory in management.

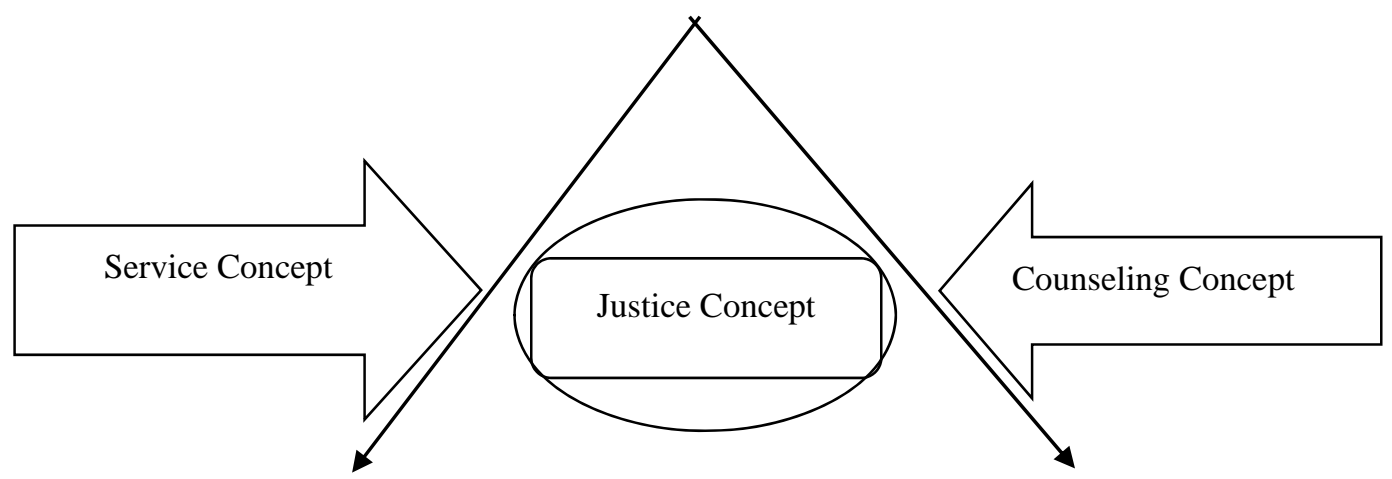

Figure 1. Arabian management theory

Source: Abu Nabaa, Abdel Aziz M. (2014). Arabian Management Theory for Sustainable Development. Journal of Baghdad College of Economic Sciences University, Special Issue for Joint Scientific Conference. 19-39. Retrieved from http://www.iasj.net/iasj?func=issues\&jId=231\&uiLanguage $=$ en

Abu Nabaa (2014) indicated that by these three concepts, he is not trying to reinvent the wheel. Because its roots are available in Islamic culture and Arab heritage, but he has tried to assemble components of steering wheel together to make the managerial carriage able of going forward. Thus if we want to change the process of the Arab manager, we have first to change the inputs of the Arab manager's mindset, so that we can have an effect on manager's mindset and improve his managerial ability. Figure 2 shows the manager's mindset inputs and outcomes of Arabian management theory: 


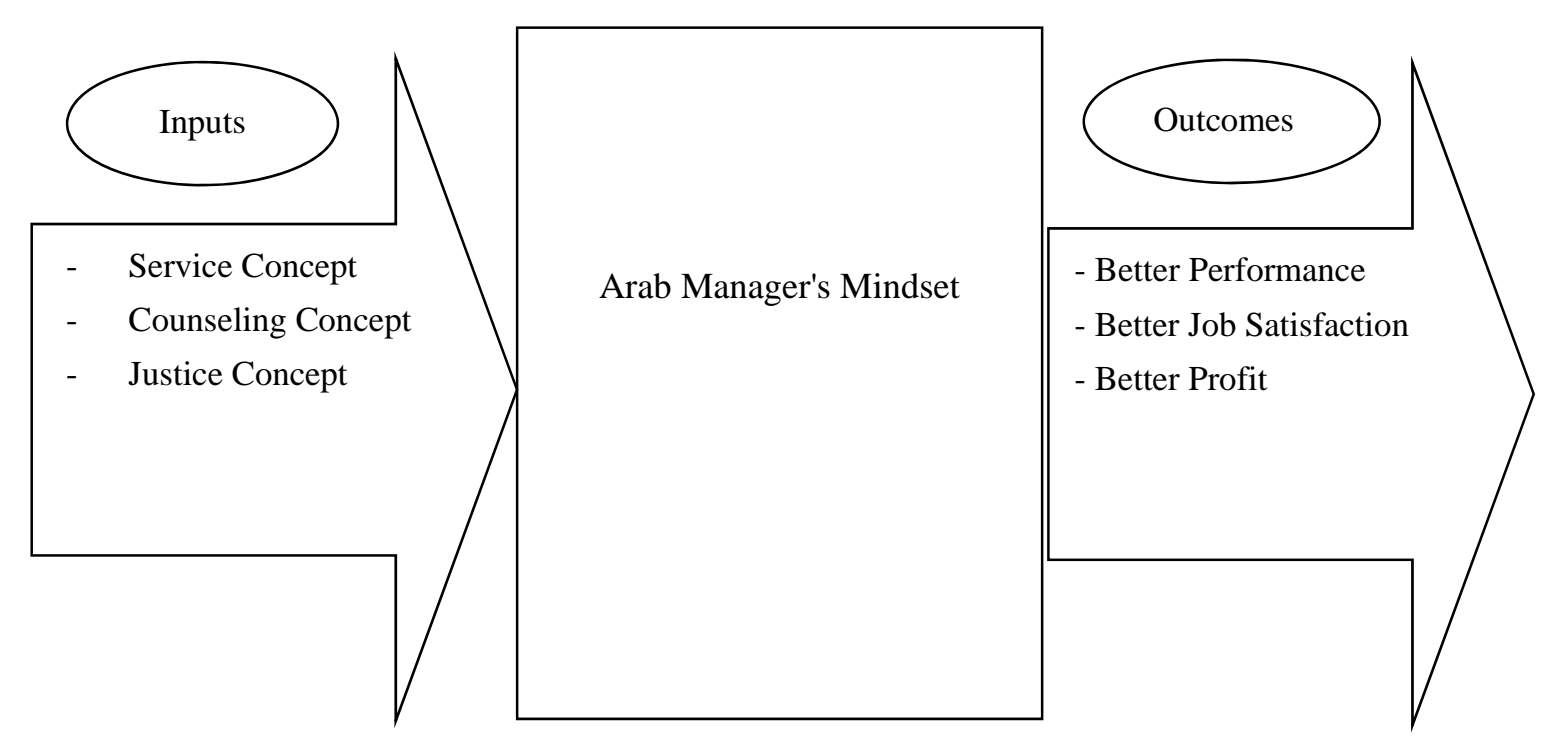

Figure 2. Arab manager's mindset model

Source: Abu Nabaa, Abdel Aziz M. (2014). Arabian Management Theory for Sustainable Development. Journal of Baghdad College of Economic Sciences University, Special Issue for Joint Scientific Conference. 19-39. Retrieved from http://www.iasj.net/iasj?func=issues\&jId=231\&uiLanguage $=$ en

After reviewing the Western theories in management, and despite its significance in enhancing the managerial thought, yet we have to realize that they grew up in dissimilar environments that are different from the Arab culture. No scholar can deny the effect of the environment on the thought of the manager's mindset (Abu Nabaa, 2014). Management is a theoretical discipline that develops continuously and rapidly. As organizations globalize, as the environment changes, as technology advances and so management theory develops (Olejniczak, 2013).

Based on Arabian management theory, the study endeavors to test the following hypotheses:

$\mathrm{H}_{1}$ : Arabian manager adoption of service concept leads to employees’ performance improvement.

$\mathrm{H}_{2}$ : Arabian manager adoption of counseling concept leads to employees' performance improvement.

$\mathrm{H}_{3}$ : Arabian manager adoption of justice concept leads to employees' performance improvement.

$\mathrm{H}_{4}$ : There are no statistically significant differences at P-value $<0.05$ in perceptions of respondents towards Arabian management theory pillars (service concept, counseling concept, and justice concept) attributable to nature of organization.

$\mathrm{H}_{5}$ : There are no statistically significant differences at P-value $<0.05$ in perceptions of respondents towards Arabian management theory pillars (service concept, counseling concept, and justice concept) attributable to their countries.

Figure 3 shows theoretical framework of the study, which consists of independent variables Arabian management theory Pillars (service concept, counseling concept, and justice concept) and dependent variable, namely employees' performance improvement. 


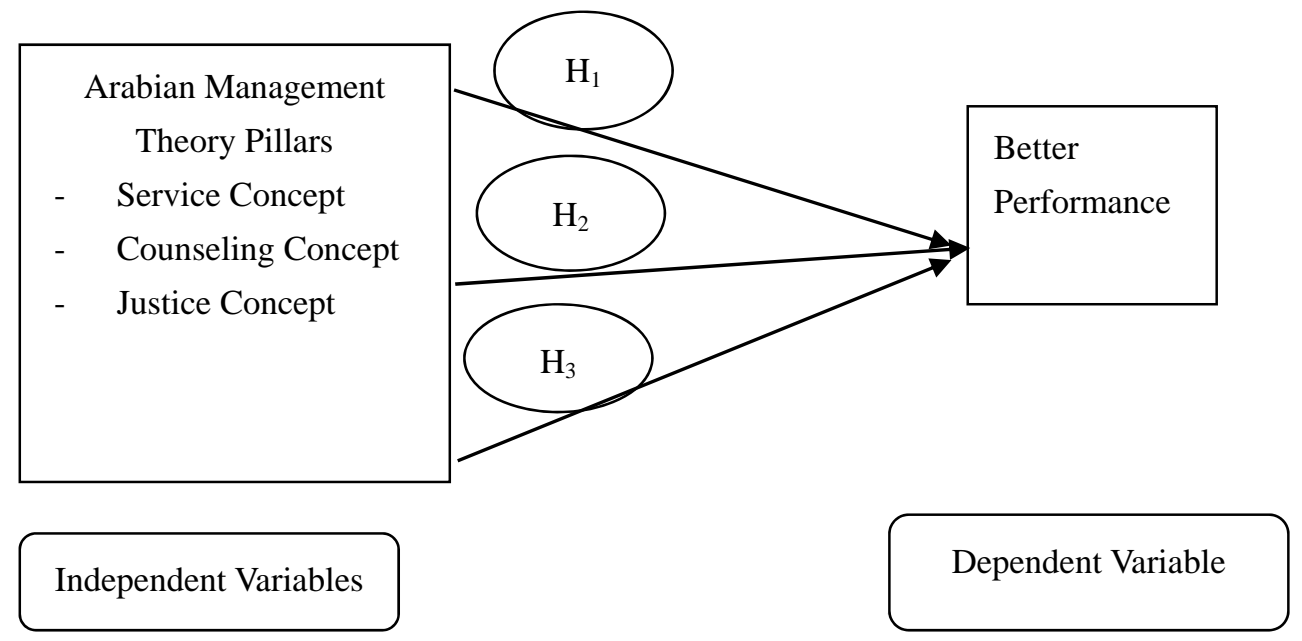

Figure 3. Theoretical framework of the study

The researcher expects that current study will be important by adding new knowledge to academics, practitioners, and organizations in Arab world. New body of knowledge may close the gap between theory and practice in terms of applying the Arabian management theory in Arabian context and its influence on employees' performance improvement.

The constructs of this study were operationalized in order to be turned in a measurable variables (Zikmund, Babin, Carr, \& Griffin, 2013; Sekaran \& Bougie, 2013) by subdividing study variables into various measurable elements to measure the following constructs; service concept, counseling concept, justice concept, and employees' performance.

\section{Research Methodology}

The study is an empirical research on private, public, civil society, and regional organizations in Arab world. To measure the impact of Arabian management theory pillars on employees' performance, a questionnaire was distributed to 385 employees at private, public, civil society, and regional organizations in 22 Arabian countries by e-mail to collect the relevant data about research constructs, and test the study hypotheses. 202 valid questionnaires were retrieved from 14 Arabian countries (Algeria, Bahrain, Egypt, Iraq, Jordan, Kuwait, Morocco, Palestine, Qatar, Saudi Arabia, Sudan, Syria, UAE, and Yemen); which represents $52.47 \%$ from distributed questionnaires and 63.64\% from Arabian countries.

\subsection{Research Tool}

Questionnaire was developed to measure Arabian management theory pillars (service concept, counseling concept, and justice concept) and employees' performance. The questionnaire contains (28) items according to quintet Likert scale.

\subsection{Validity of Research Tool}

Statistical Package for the Social Sciences (SPSS) was used to analyze data of the study. The researcher has designed all study results in tables 1-9 based on SPSS analyses. 
Table 1. Arabian management theory factor loadings and reliability of the constructs

\begin{tabular}{|c|c|c|c|}
\hline $\begin{array}{l}\text { Alpha Cronbach } \\
\text { Items }\end{array}$ & $\begin{array}{l}0.862 \\
\text { Service Concept }\end{array}$ & $\begin{array}{l}0.916 \\
\text { Counseling Concept }\end{array}$ & $\begin{array}{l}0.886 \\
\text { Justice Concept }\end{array}$ \\
\hline Service1 & .551 & & \\
\hline Service2 & .747 & & \\
\hline Service3 & .780 & & \\
\hline Service4 & .785 & & \\
\hline Service5 & .638 & & \\
\hline Service6 & .726 & & \\
\hline Service7 & .774 & & \\
\hline Service8 & .573 & & \\
\hline Service9 & .639 & & \\
\hline Counseling 1 & & .787 & \\
\hline Counseling 2 & & .734 & \\
\hline Counseling 3 & & .784 & \\
\hline Counseling 4 & & .743 & \\
\hline Counseling 5 & & .782 & \\
\hline Counseling 6 & & .824 & \\
\hline Counseling 7 & & .788 & \\
\hline Counseling 8 & & .717 & \\
\hline Counseling 9 & & .804 & \\
\hline Counseling 10 & & .618 & \\
\hline Justice 1 & & & 688 \\
\hline Justice2 & & & .742 \\
\hline Justice3 & & & .814 \\
\hline Justice4 & & & .786 \\
\hline Justice5 & & & .675 \\
\hline Justice6 & & & .825 \\
\hline Justice7 & & & .651 \\
\hline Justice8 & & & .620 \\
\hline Justice9 & & & .755 \\
\hline
\end{tabular}

All items loadings are significant at P-value $<0.05$.

Factor analysis was conducted to extract Arabian management theory constructs by using varimax rotation to determine variance explained. The researcher used 0.5 as threshold of primary loading according to Chen, Soliman, Mao, and Frolick (2000) who adopted 0.5 as threshold of primary loading in their study. Three constructs of Arabian management theory were revealed as a result of the factor analysis. The factor loadings is ranged from 0.551 to 0.825 as shown in the Table 1 .

\subsection{Reliability of Research Tool}

Cronbach alpha coefficient was extracted to verify the internal consistency of the variables. Table 1 displays reliability coefficients of service concept, counseling concept, and justice concept constructs that exceeded 70\%, which is an acceptable measurement for analysis.

\section{Research Findings}

\subsection{Perceptions of Respondents about the Study Variables}

To measure perceptions of respondents about the study constructs, the significance level of the answers to the research tool items was adopted according to the following formula:

Category Length $=$ (maximum response limit-minimum response limit) $/$ number of importance levels.

Category Length $=(5-1) / 3=1.33$

Based on mean, low significance level is ranging from 1-2.33, moderate significance level is ranging from 2.34-3.66, and high significance level is ranging from 3.67-5. 


\subsubsection{Perceptions of Respondents about Service Concept}

A review of Table 2 displays that the means of all items of the service concept are high with general mean (4.0968). This is consistent with the old Arab proverb says that "the leader is the servant of his community" (Abu Nabaa, 2014, p. 29).

Table 2. Mean, standard deviation, and significance level for items of service concept

\begin{tabular}{|c|c|c|c|}
\hline Item & Mean & S.D. & Sig. Level \\
\hline $\begin{array}{l}\text { Manager's eagerness to achieve the goals of employees along with the } \\
\text { organization's goals is leading to improve their performance. }\end{array}$ & 4.1931 & .90732 & High \\
\hline $\begin{array}{l}\text { Manager's listening to employees' views in my organization is leading to } \\
\text { improve their performance. }\end{array}$ & 4.2327 & .81058 & High \\
\hline $\begin{array}{l}\text { Manager's appreciation to employees' capabilities in my organization is leading } \\
\text { to improve their performance. }\end{array}$ & 4.2574 & .77464 & High \\
\hline $\begin{array}{l}\text { Manager's eagerness to meet employees' needs in my organization is leading to } \\
\text { improve their performance. }\end{array}$ & 4.1733 & .88923 & High \\
\hline $\begin{array}{l}\text { Manager's putting himself -in any situation- in employees' shoes is leading to } \\
\text { improve their performance in my organization. }\end{array}$ & 3.7921 & .89573 & High \\
\hline $\begin{array}{l}\text { Manager's appreciation to retirees of my organization is leading to improve } \\
\text { employees' performance. }\end{array}$ & 3.9158 & .97115 & High \\
\hline $\begin{array}{l}\text { Manager's gratefulness to distinguished employees in my organization is leading } \\
\text { to improve their performance. }\end{array}$ & 4.1881 & .83115 & High \\
\hline $\begin{array}{l}\text { Manager's positive criticism to employees -start with strengths then } \\
\text { improvement areas- in my organization is leading to improve their performance. }\end{array}$ & 3.9257 & .79765 & High \\
\hline $\begin{array}{l}\text { Manager's care of employees' circumstances in my organization is leading to } \\
\text { improve their performance. }\end{array}$ & 4.1931 & .71748 & High \\
\hline General Mean & 4.0968 & & High \\
\hline
\end{tabular}

\subsubsection{Perceptions of Respondents about Counseling Concept}

Table 3 shows that the means of all items of counseling concept are high with a general mean (4.1302). This is consistent with Ali Bin Abi Taleb’s saying: "counseling and dialogue are a door to mercy where no opinion goes astray" (Abu Nabaa, 2014, p. 33).

Table 3. Mean, standard deviation, and significance level for items of counseling concept

\begin{tabular}{|c|c|c|c|}
\hline Item & Mean & S.D. & Sig. Level \\
\hline $\begin{array}{l}\text { Manager's consultation of employees in my organization is leading to improve } \\
\text { their performance. }\end{array}$ & 4.1832 & .90938 & High \\
\hline $\begin{array}{l}\text { Manager's solution of the problems faced by employees in my organization is } \\
\text { leading to improve their performance. }\end{array}$ & 4.1485 & .79659 & High \\
\hline $\begin{array}{l}\text { Manager's meeting periodically with employees in my organization is leading to } \\
\text { improve their performance. }\end{array}$ & 3.9950 & .83158 & High \\
\hline $\begin{array}{l}\text { Open communication between manager and employees in my organization is } \\
\text { leading to improve their performance. }\end{array}$ & 4.0842 & .82730 & High \\
\hline $\begin{array}{l}\text { Collective management in my organization is leading to improve employees' } \\
\text { performance. }\end{array}$ & 3.9505 & .96585 & High \\
\hline $\begin{array}{l}\text { Mutual trust between manager and employees in my organization is leading to } \\
\text { improve their performance. }\end{array}$ & 4.2228 & .70172 & High \\
\hline $\begin{array}{l}\text { Manager's wisdom in dealing with issues at work in my organization is leading } \\
\text { to improve their performance. }\end{array}$ & 4.2079 & .73730 & High \\
\hline $\begin{array}{l}\text { Manager's discussion with distinguished employees in my organization is } \\
\text { leading to improve their performance. }\end{array}$ & 4.2030 & .87155 & High \\
\hline $\begin{array}{l}\text { Manager's allowing employees' opinions without fear in my organization is } \\
\text { leading to improve their performance. }\end{array}$ & 4.1584 & .86654 & High \\
\hline $\begin{array}{l}\text { Manager's respect of time when attending meetings with employees in my } \\
\text { organization is leading to improve their performance. }\end{array}$ & 4.1485 & .77762 & High \\
\hline General Mean & 4.1302 & & High \\
\hline
\end{tabular}




\subsubsection{Perceptions of Respondents about Justice Concept}

Table 4 demonstrates that the mean of items of justice concept are high with a general mean (4.0699). This is consistent with Prophet Mohammad's saying: "Three judges: one goes to paradise and the other two go to hell”, Therefore, a manager in his office at organization is a judge, and he has to be fair with his employees (Abu Nabaa, 2014, p. 36).

Table 4. Mean, standard deviation, and significance level for items of justice concept

\begin{tabular}{|c|c|c|c|}
\hline Item & Mean & S.D. & Sig. Level \\
\hline $\begin{array}{l}\text { Manager's justice in dealing with employees in my organization is leading to } \\
\text { improve their performance. }\end{array}$ & 4.0396 & .86296 & High \\
\hline $\begin{array}{l}\text { Manager's giving incentive for eligible employees in my organization is leading } \\
\text { to improve their performance. }\end{array}$ & 4.2178 & .81776 & High \\
\hline $\begin{array}{l}\text { Manager's granting promotion to eligible employees in my organization is } \\
\text { leading to improve their performance. }\end{array}$ & 4.2079 & .90677 & High \\
\hline $\begin{array}{l}\text { Manager's granting bonuses to employees in accordance with the regulations } \\
\text { and instructions in my organization is leading to improve their performance. }\end{array}$ & 4.0446 & .88828 & High \\
\hline $\begin{array}{l}\text { Manager's unacceptance of patronage in decisions concerning employees in my } \\
\text { organization is leading to improve their performance. }\end{array}$ & 3.9901 & .94627 & High \\
\hline $\begin{array}{l}\text { Manager's evaluation objectively for employees' performance in my } \\
\text { organization is leading to improve their performance. }\end{array}$ & 4.0347 & .84275 & High \\
\hline $\begin{array}{l}\text { Not listening for hypocrites in my organization is leading to improve employees' } \\
\text { performance. }\end{array}$ & 3.9604 & 1.07824 & High \\
\hline $\begin{array}{l}\text { Manager's evaluation for employees based on job description in my organization } \\
\text { is leading to improve their performance. }\end{array}$ & 3.8812 & .95456 & High \\
\hline $\begin{array}{l}\text { Fear of Allah by manager at his work in my organization is leading to improve } \\
\text { employees' performance. }\end{array}$ & 4.2525 & .82294 & High \\
\hline General Mean & 4.0699 & & High \\
\hline
\end{tabular}

\subsection{Hypotheses Testing}

$\mathbf{H}_{\mathbf{1}}$ : Arabian manager adoption of service concept leads to employees’ performance improvement

T-Test analysis in table 5 indicates that there is a statistical effect of service concept on employees' performance at organizations in Arab world; where t-value is significant at P-value $=.000$. Thus, hypothesis H1 is accepted.

Table 5. Results of T-Test analysis of the effect of service concept on employees’ performance

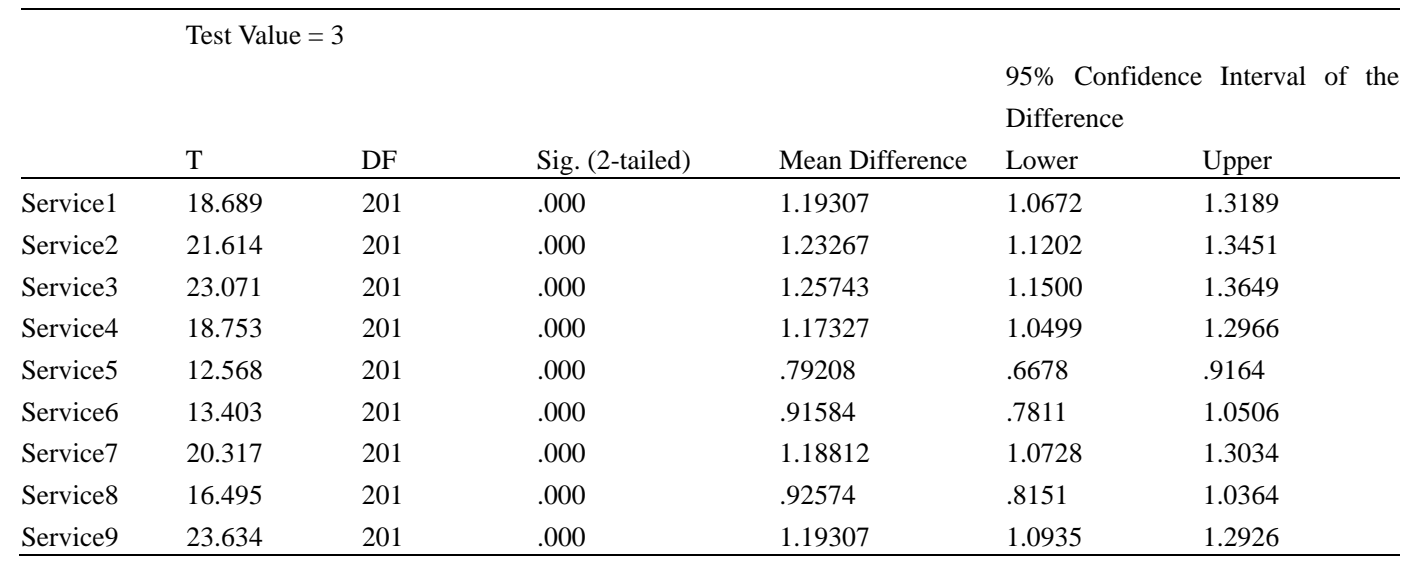

$\mathbf{H}_{2}$ : Arabian manager adoption of counseling concept leads to employees' performance improvement

T-Test analysis in Table 6 indicates that there is a statistical effect of counseling concept on employees' performance at organizations in Arab world; where t-value is significant at P-value $=.000$. Thus, hypothesis H2 is accepted. 
Table 6. Results of t-test analysis of the effect of counseling concept on employees’ performance

\begin{tabular}{|c|c|c|c|c|c|c|}
\hline & \multicolumn{6}{|c|}{ Test Value $=3$} \\
\hline & \multirow[b]{2}{*}{$\mathrm{T}$} & \multirow[b]{2}{*}{$\mathrm{DF}$} & \multirow[b]{2}{*}{ Sig. (2-tailed) } & \multirow[b]{2}{*}{ Mean Difference } & \multicolumn{2}{|c|}{$\begin{array}{l}\text { 95\% Confidence Interval of the } \\
\text { Difference }\end{array}$} \\
\hline & & & & & Lower & Upper \\
\hline Counseling 1 & 18.492 & 201 & .000 & 1.18317 & 1.0570 & 1.3093 \\
\hline Counseling 2 & 20.492 & 201 & .000 & 1.14851 & 1.0380 & 1.2590 \\
\hline Counseling 3 & 17.007 & 201 & .000 & .99505 & .8797 & 1.1104 \\
\hline Counseling 4 & 18.625 & 201 & .000 & 1.08416 & .9694 & 1.1989 \\
\hline Counseling 5 & 13.987 & 201 & .000 & .95050 & .8165 & 1.0845 \\
\hline Counseling 6 & 24.766 & 201 & .000 & 1.22277 & 1.1254 & 1.3201 \\
\hline Counseling 7 & 23.285 & 201 & .000 & 1.20792 & 1.1056 & 1.3102 \\
\hline Counseling 8 & 19.617 & 201 & .000 & 1.20297 & 1.0821 & 1.3239 \\
\hline Counseling 9 & 19.000 & 201 & .000 & 1.15842 & 1.0382 & 1.2786 \\
\hline Counseling 10 & 20.991 & 201 & .000 & 1.14851 & 1.0406 & 1.2564 \\
\hline
\end{tabular}

$\mathbf{H}_{3}$ : Arabian manager adoption of justice concept leads to employees' performance improvement

T-Test analysis in Table 7 indicates that there is a statistical effect of justice concept on employees' performance at organizations in Arab world; where t-value is significant at P-value $=.000$. Thus, hypothesis $\mathrm{H} 3$ is accepted.

Table 7. Results of t-test analysis of the effect of justice concept on employees' performance

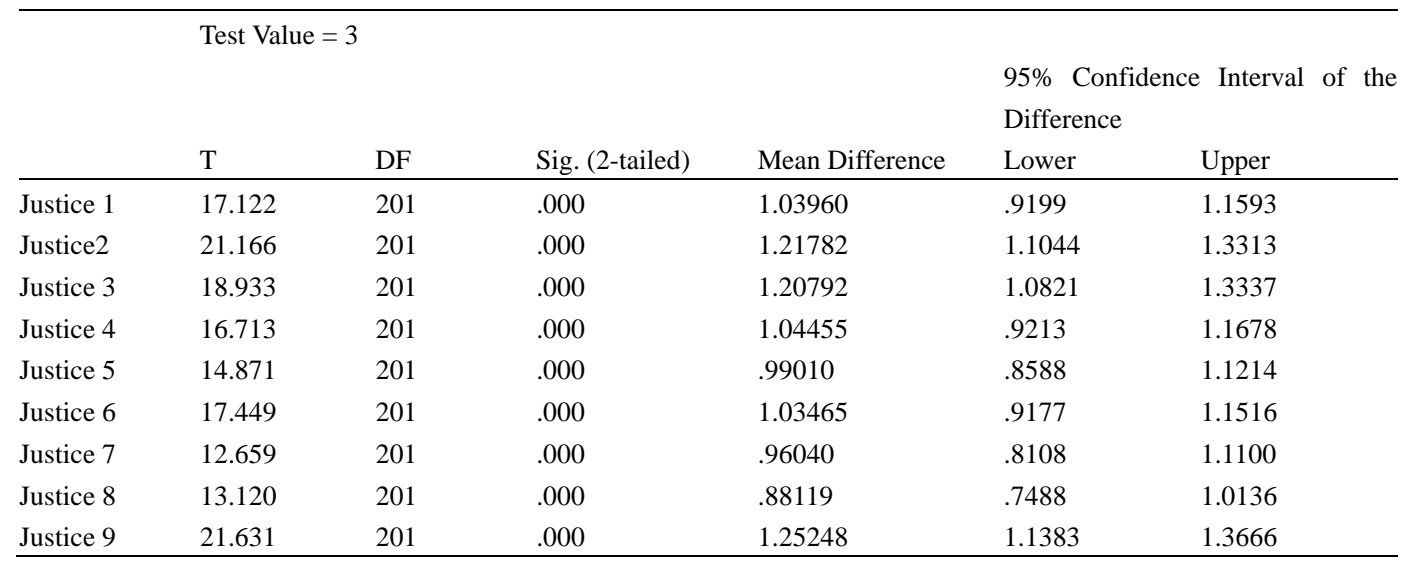

$\mathbf{H}_{4}$ : There are no statistically significant differences at P-value $<0.05$ in perceptions of respondents towards Arabian management theory pillars (service concept, counseling concept, and justice concept) attributable to nature of organization.

The results of ANOVA in table 8 show that there are no statistical significant differences at P-value $<0.05$ in perceptions of respondents towards Arabian management theory pillars (service concept, counseling concept, and justice concept) attributable to nature of organization (private, public, civil society, and regional organizations); $\mathrm{P}=.933, .077$ and .250 consecutively. Thus, hypothesis $\mathrm{H} 4$ is accepted. 
Table 8. Results of ANOVA of perceptions of respondents towards Arabian management theory pillars attributable to nature of organization

\begin{tabular}{lllllll}
\hline \multirow{5}{*}{ Service } & & Sum of Squares & DF & Mean Square & F & Sig. \\
& Between Groups & .150 & 3 & .050 & .144 & .933 \\
& Within Groups & 62.071 & 179 & .347 & & \\
& Total & 62.221 & 182 & & & \\
\multirow{5}{*}{ Justice } & 2.741 & 3 & .914 & 2.318 & .077 \\
& Between Groups & 70.552 & 179 & .394 & & \\
& Within Groups & 73.293 & 182 & & & \\
& Total & 1.796 & 3 & .599 & .250 \\
& Between Groups & 77.522 & 179 & .433 & & \\
& Within Groups & 79.318 & 182 & & &
\end{tabular}

$\mathbf{H}_{5}$ : There are no statistically significance differences at P-value $<0.05$ in perceptions of respondents towards Arabian management theory pillars (service concept, counseling concept, and justice concept) attributable to their countries.

Table 9. Results of ANOVA of perceptions of respondents towards Arabian management theory pillars attributable to their countries

\begin{tabular}{lllllll}
\hline \multirow{5}{*}{ Service } & & Sum of Squares & DF & Mean Square & F & Sig. \\
& Between Groups & 5.135 & 13 & .395 & 1.169 & .306 \\
& Within Groups & 57.086 & 169 & .338 & & \\
Counseling & Total & 62.221 & 182 & & & \\
& Between Groups & 6.598 & 13 & .508 & 1.286 & .225 \\
& Within Groups & 66.694 & 169 & .395 & & \\
& Total & 73.293 & 182 & & & \\
& Bustice & 8.113 & 13 & .624 & .481 & .129 \\
& Within Groups & 71.205 & 169 & .421 & & \\
& Total & 79.318 & 182 & & & \\
\hline
\end{tabular}

The results of ANOVA in Table 9 show that there is no statistical significant differences at P-value $<0.05$ in perceptions of respondents towards Arabian management theory pillars (service concept, counseling concept, and justice concept) attributable to their countries (Algeria, Bahrain, Egypt, Iraq, Jordan, Kuwait, Morocco, Palestine, Qatar, Saudi Arabia, Sudan, Syria, UAE, and Yemen); P =.306, .225 and .129 consecutively. Thus, hypothesis $\mathrm{H} 5$ is accepted.

\section{Conclusion}

The aim of this research is to examine the possibility of applying Arabian management theory by measuring the impact of Arabian management theory pillars on employees’ performance.

The perceptions of respondents about all items of Arabian management theory pillars (service concept, counseling concept, and justice concept) are high. This indicates that Arabian management theory is possible to be applied in the Arab nations. The researcher concludes that applying Arabian management theory required recruit and hire leaders who believe in Islamic values and Arab culture due to the effect of the pillars of Islam on managers' style and behavior (Abuznaid, 2006).

The results demonstrate that there are statistical effects of Arabian management theory pillars (service concept, counseling concept, and justice concept) on employees' performance at organizations in Arab world. These results agree with principles of Abu Nabaa's theory (2005). This indicates that Arabian management theory pillars (service concept, counseling concept, and justice concept) is applicable in Arabian environment and consistent with Arab culture and Islamic heritage.

The results show that there are no statistical differences in perceptions of respondents towards Arabian management theory pillars (service concept, counseling concept, and justice concept) attributable to nature of organization (private, public, civil society, and regional organizations). This indicates that Abu Nabaa's theory (2005) is possible to be applied at all kinds of Arab organizations in the Arab nations. 
The results illustrate that there are no statistical differences in perceptions of respondents towards Arabian management theory pillars (service concept, counseling concept, and justice concept) attributable to their countries. This indicates that Abu Nabaa's theory (2005) is possible to be applied in all Arab nations.

\section{Implications}

Since there are positive effects of Arabian management theory pillars on employees' performance at various organizations in Arab world, it is necessary to apply Arabian management theory to improve performance.

Since there are no statistical differences in perceptions of respondents towards Arabian management theory pillars attributable to nature of organization and Arab nations, the researcher recommends that Arabian management theory can be applied at all kinds of organizations in Arab nations.

\section{Limitations and Future Studies}

Since the study measures the effects of Arabian management theory pillars on employees' performance only, future studies could be conducted in terms of Arabian management theory pillars on job satisfaction and other related constructs.

\section{References}

Abu Nabaa, A. A. M. (2014). Arabian Management Theory for Sustainable Development. Journal of Baghdad College of Economic Sciences, 19-39. Retrieved from http://www.iasj.net/iasj?func=issues\&jId=231\&uiLanguage $=$ en

Abu Nabaa, A. A. M. (2005). Toward Developing an Arabian Theory in Management. Amman: Alwaraq for Publishing.

Abuznaid, S. (2006). Islam and Management: What can be learned? Thunderbird International Business Review, 48(1), 125-139. http://dx.doi.org/10.1002/tie.20089V

AL-Ameri, S. M., \& AL-Ghalibi, T. M. (2013). Management and Business (4th ed.). Amman: Dar Wael.

Ali, A. J. (1990). Management theory in a Transitional Society: The Arab's Experience. International Studies of Management \& Organization, 20(3), 7-35.

Ali, A. J. (1996). Organizational Development in the Arab world. Journal of Management Development, 15(5), 4-21. http://dx.doi.org/10.1108/02621719610117213

Alghazawi, R., Waheeb, M., \& Kraisha, D. (2015). Cultural Heritage Management Adaptation in the Arab World: Review \& Perspectives. Mediterranean Archaeology and Archaeometry, 15(1), 11-21.

AL-Kasasbeh, M., AL-Faouri, A., \& Al-Hyasat, K. (2012). Ibn Taimiyah’s Contributions in Managerial Thought. International Journal of Islamic Marketing, 1(3), 31-41.

AL-Kasasbeh, M., AL-Kasasbeh, S., \& AL-Faouri, A. (2016). Smart Organization Characteristics and its Impact on Social and Environmental Performance: An Empirical Study on Jordan Phosphate Mines Company. International Journal of Business and Management, 11(8), 106-115. http://dx.doi.org/10.5539/ijbm.v11n8p106

Alyousif, A., Naoum, S., Atkinson, A., \& Robinson, H. (2010). National Culture Influence on Management Practices in the Construction Industry of United Arab Emirates. In C. Egbu (Ed.), Association of Researchers in Construction Management, Procs 26th Annual ARCOM Conference (pp. 511-520). UK.

Badawy, M. K. (1980). Styles of Mideastern Managers. California Management Review, 22(3), 51.

Butkus, F. S. (2010). Applying Management Theory to the Analysis of the Life of Various Human Communities. Business and Management, 595-602. http://dx.doi.org/10.3846/bm.2010.079

Chen, L. D., Soliman, K. S., Mao, E., \& Frolick, M. (2000). Measuring User Satisfaction with Data Warehouses: An Exploratory Study. Information \& Management, 37(3), 103-110.

Daft, R. L. (2013). New Era of Management (11th ed.). South-Western.

Hammoudeh, M. M. (2012). Islamic Values and Management Practices Quality and Transformation in the Arab World. England: Gower Publishing Limited.

Jones, T. M., Donaldson, T., Edward, R. F., Harrison, J. S., Leana, C. R., Mahoney, J. T., \& Pearce, J. L. (2016). Introduction to Special Topic Forum Management Theory and Social Welfare: Contributions and Challenges. Academy of Management Review, 41(2), 216-228. http://dx.doi.org/10.5465/Amr.2016.0012

Marti, E., \& Scherer, A. G. (2016). Financial Regulation and Social Welfare: The Critical Contribution of 
Management Theory. Academy of Management Review, 41(2), 298-323.

Obeidat, B. Y., Shannak, R. O., Masa'deh, R., \& Al-Jarrah, I. M. (2012). Toward Better Understanding for Arabian Culture: Implications Based on Hofstede’s Cultural Model. European Journal of Social Sciences, 28(40), 512-522.

Olejniczak, T. (2013). Japanese Management: 50 Years of Evolution of the Concept. Retrieved from https://www.google.jo/?gfe_rd=cr\&ei=_EhwV7vGPLKs8wf3sYH4Dw\#q=japanese+management+theory\& start $=10$

Robbins, S. P., DeCenzo, D. A., \& Coulter. (2013). Fundamentals of Management (8th ed.). Prentice Hall, Inc.

Saikat, B. S. (2005). Management \& Organizational Theory in Cross-Cultural Work Environments. Thesis Submitted to College Leonard N. Stern School of Business, New York University.

Sekaran, U., \& Bougie, R. (2013). Research Methods for Business: A Skill-Building Approach (6th ed.). John Wiley and Sons Inc.

Smith, P. B., Achoui, M., \& Harb, C. (2007). Unity and Diversity in Arab Managerial Styles. International Journal of Cross Cultural Management, 7(3), 275-290. http://dx.doi.org/10.1177/1470595807083374

Zikmund, W. G., Babin, B. J., Carr, J. C., \& Griffin, M. (2013). Business Research Methods (9th ed.). Australia South-Western.

\section{Copyrights}

Copyright for this article is retained by the author(s), with first publication rights granted to the journal.

This is an open-access article distributed under the terms and conditions of the Creative Commons Attribution license (http://creativecommons.org/licenses/by/4.0/). 